\title{
STIMULASI HASIL MELON (Cucumis melo, L) DENGAN MENGGUNAKAN BIOTO GROW GOLD (BGG)
}

\author{
Sahindah Aritonang ${ }^{1}$, Surtinah Surtinah ${ }^{1}$ \\ ${ }^{1}$ Prodi Agroteknologi Fakultas Pertanian Universitas Lancang Kuning \\ e-mail: surtinah@unilak.ac.id
}

\begin{abstract}
ABSTRAK
Penelitian dilaksanakan secara eksperimen dengan menggunakan Rancangan Acak Lengkap (RAL) non faktorial dengan 5 (lima) taraf perlakuan yaitu tanpa pemberian Bioto Grow Gold, pemberian Bioto Grow Gold $1 \mathrm{ml}$ liter $^{-1}$ air, pemberian Bioto Grow Gol $2 \mathrm{ml} \mathrm{liter}{ }^{-1}$ air, pemberian Bioto Grow Gold $3 \mathrm{ml}$ liter $^{-1}$ air dan pemberian Bioto Grow Gold $4 \mathrm{ml} \mathrm{liter}^{-1}$ air. Analisis data menggunakan sidik ragam dan dilanjutkan dengan uji beda rata-rata perlakuan Duncan pada $\mathrm{p}$ 0.05. Hasil penelitian memperlihatkan bahwa perlakuan BGG berpengaruh nyata terhadap panjang daun, lebar daun, diameter batang, umur berbunga, lingkar buah, berat buah, tebal daging buah dan kadar gula daging buah melon. Perlakuan terbaik yaitu pemberian Bioto Grow Gold $3 \mathrm{ml}$ liter $^{-1}$ air.
\end{abstract}

Kata kunci: Bioto Grow Gold, Melon.

\section{ABSTRACT}

The experiment was conducted experimentally using non-factorial Randomized Design (RAL) with 5 (five) treatment levels without Bioto Grow Gold, Bioto Grow Gold $1 \mathrm{ml}$ liter ${ }^{-1}$ water, Bioto Grow Gold $2 \mathrm{ml} \mathrm{liter}^{-1}$ water, giving Bioto Grow Gold $3 \mathrm{ml} \mathrm{liter}^{-1}$ water and giving Bioto Grow Gold $4 \mathrm{ml}$ liter ${ }^{-1}$ water. The data analysis used variance and continued with a different test of Duncan treatment average at $p$ 0.05. The results showed that BGG treatment had the significant effect on leaf length, leaf width, stem diameter, flowering age, fruit circumference, fruit weight, a thickness of flesh and sugar content of melon fruit. The best treatment is giving Bioto Grow Gold 3 ml liter $^{-1}$ water.

Keywords: Bioto Grow Gold, Melon .

Diterima: 16 Juli 2018, disetujui 26 Juli 2018

\section{PENDAHULUAN}

Melon (Cucumis melo, L), merupakan salah satu produk hortikultura yang dapat dikembangkan di dataran rendah. Permintaan buah melon di Pekanbaru terus meningkat dengan peningkatan jumlah penduduk. Kesadaran akan bahan pangan yang sehat berdampak dengan meningkatnya permintaan untuk memnuhi kebutuhan bahan pangan tersebut.

Melon dengan kandungan gizi yang dimilikinya menjadi salah satu buah yang diminati oleh masyarakat. Selain gizi yang terkandung di dalam buah melon, serat yang dihasilkan oleh buah melon tinggi, sehingga dapat memperbaiki system pencernaan dalam memcegah konstipasi, sehingga menghindari timbulnya ambeien.

Produksi melon di Riau sangat rendah, salah satu yang menyebabkannya 
adalah kondisi tanah yang sedikit mengandung bahan organic, tetapi kurangnya bahan organic pada tanah dapat di atasi dengan penambahan bahan organic pada tanah pada budidaya jagung manis (Surtinah, dan Nurwati, 2018). Penambahan bahan organic yang diikuti dengan penambahan unsur hara melalui pemberian pupuk, akan memacu pertumbuhan dan produksi tanaman (Surtinah, 2017 a). Primantoro (2002) menambahkan bahwa pemupukan merupakan upaya yang dapat diberikan untuk mengatasi kondisi tanah yang kekurangan unsur hara, sehingga kebutuhan tanaman akan dapat terpenuhi.

Bioto Grow Gold (BGG) adalah salah satu pupuk organik hayati yang akan diuji kemampuannya dalam memperbaiki kondisi tanah di lokasi penelitian ini. BGG mengandung unsur hara makro dan mikro, juga dilengkapi dengan mikroorganisme serta zat pengatur tumbuh, seperti Auksin, Sitokinin, dan Giberelin . mikroorganisme yang terkandung di dalam BGG antara lain Actinomycetes, Azotobacter sp, Azospirillium sp, Rhizobium sp, Psedomonas, Lactobacillus sp, Bacilus sp, Cytophaga sp, Streptomycetes sp, Saccharomyces, Selulotik, BPF, Mycoriza, Tricoderma, sedangkan kandungan bahan organik diantaranya $2 \%$, organik $7,5 \%$, $\mathrm{N} 2,35 \%, \mathrm{P} 2053,5 \%, \mathrm{~K}_{2} \mathrm{O} 2,24 \%, \mathrm{CaO}$ $1,1 \%, \mathrm{MgO} 0,1 \%, \mathrm{~S} 1 \%$, Fe 0,58 \%, Mn $0,3 \%$, B 2250,80 ppm, Mo 0,01\%, Cu 6,8 ppm, Zn 0,2\%, Cl 0,001\% dan juga Zat Pengatur Tumbuh Auksin 170 ppm, Giberelin 225 ppm, Kinetin 99,7 ppm, Zeatin 99,5 ppm (Anonim, 2014).

\section{METODE PENELITIAN}

Penelitian ini telah dilaksanakan di Kebun Percobaan Fakultas Pertanian Universitas Lancang Kuning dengan ketinggian 20 meter dpl. dan topografi datar, jenis tanah Podzolik Merah Kuning
Mikroorganisme yang terkandung di dalam dalam BGG seperti bakteri pelarut posfat yang dapat menyediakan Posfat tersedia bagi tanaman, Lactobacillus yang berperan dalam penguraian bahan organic, bakteri selulotik yang mampu mengurai selulosa menjadi monomer glukosa dan menjadi sumber karbon dan sumber energy (Susi, Surtinah, dan Rizal, 2017). Arnianty (2008) melaporkan bahwa Pseudomonas $s p$ dapat menstimulir timbulnya ketahanan tanaman terhadap infeksi jamur pathogen akar, bakteri dan virus.

Azotobacter sp dan Azospirillum $s \mathrm{p}$ berperan sebagai penambat Nitrogen dan digunakan untuk menstimulir pertumbuhan vegetatif tanaman. Nitrogen yang diperoleh tanaman secara tidak langsung dapat mempengaruhi pertumbuhan dan produksi tanaman. Nitrogen merupakan salah satu komponen pembentuk klorofil yang berperan dalam penangkapan cahaya pada proses fotosintesis, dan hasil fotosintesis berupa fotosintat yang merupakan makanan bagi tanaman (Surtinah, 2017 b). Tanaman jagung manis yang diberi pupuk NPK dapat mencapai berat tongkol berkelobot seberat 511,67 gram untuk varietas Bintang Asia ( Surtinah, Susi, dan Lestari, 2016). Pertumbuhan vegetatif seperti jumlah daun dan panjang daun memiliki hubungan yang erat dengan pembentukan gula biji jagung manis (Surtinah, 2017 c) . Tujuan penelitian adalah untuk mendapatkan konsentrasi BGG yang memberikan pertumbuhan dan produksi melon tertinggi.

(PMK). Penelitian dimulai dari bulan November sampai Januari 2017.

Bahan yang digunakan dalam penelitian ini adalah media tanah top soil PMK, benih Melon varietas Sakata Glamour, pupuk kandang sapi, pupuk 
hayati cair Bioto Grow Gold, Petrogenol, Dithane M- 45, Curacron 500 EC, baby polybag, tali rafia, ajir, paku dan NPK Mutiara 16:16:16.

Rancangan perlakuan yang diuji adalah Tanpa pemberian Bioto Grow Gold (B0); Pemberian Bioto Grow Gold $1 \mathrm{ml}$ liter $^{-1}$ air (B1); Pemberian Bioto Grow Gold 2 ml liter ${ }^{-1}$ air (B2); Pemberian Bioto Grow Gold $3 \mathrm{ml}$ liter $^{-1}$ air; dan Pemberian Bioto Grow Gold $4 \mathrm{ml} \mathrm{liter}^{-1}$ air. Rancang lingkungan yang digunakan adalah rancangan acak lengkap, dengan empat kali ulangan. Data dianalisis dengan menggunakan sidik ragam pada $p$ 0.05. dilanjutkan dengan uji beda rata-rata perlakuan Duncan pada peluang 0.05.

Pengolahan tanah dilakukan dua kali, pada pengolahan tanah yang kedua sekaligus membuat plot dengan ukuran $160 \times 100 \mathrm{~cm}$. pada pengolahan tanah kedua dilakukan pencampuran pupuk kandang dengan dosis 30 ton hektar ${ }^{-1}$.

Persemaian benih menggunakan tanah top soil yang dicampur pupuk kandang dengan perbandingan 2:1. Persemaian menggunakan polybag ukuran $8 \times 12 \mathrm{~cm}$. benih yang disemai direndam selama 10 jam, selanjutnya diletakkan di atas kasa. Setelah berkecambah dipindahkan ke polybag persemaian. Pemindahan bibit ke lokasi penanaman pada saat bibit berumur 14 hari. Bibit ditanam dengan jarak tanam 80 x $50 \mathrm{~cm}$.

Perlakuan BGG diberikan 15 hari setelah pindah tanam. BGG yang diberikan dilarutkan terlebih dahulu sesuai dengan konsentrasi perlakuan, diberikan dengan interval 7 hari, dan dihentikan 7 hari menjelang panen.

\section{HASIL DAN PEMBAHASAN}

Pertumbuhan Vegetatif dan Generatif Tanaman Melon,

Hasil analisis data dan uji beda rata-rata pertumbuhan vegetatif akibat
Tanaman melon diberi lanjaran dua hari setelah pindah tanam, panjang lanjaran yang digunakan adalah 2 meter. Pupuk NPK Mutiara 16:16:16 diberi setengah dosis anjuran yaitu 40 gram tanaman $^{-1}$, dan diberikan 4 kali dengan dosis 10 gram $\operatorname{tanaman}^{-1}$ tiap kali pemberian, dan pemberian dilakukan dengan interval dua minggu.

Pemangkasan terhadap tunas atau cabang dilakukan mulai ruas pertama sampai ruas ke delapan. Tunas pada ruas ke 9 sampai ke 13 dibiarkan tidak dipangkas. Pada ruas ke 25 dilakukan pemotongan ujung tanaman untuk memberi kesempatan tunas berkembang untuk menghasilkan produksi. Seleksi buah dilakukan pada saat buah sebesar telur ayam, dan buah yang dibiarkan tumbuh berkembang adalah dua buah tanaman $^{-1}$. Buah yang dipelihara diikat agar tidak jatuh, pengikatan dilakukan pada umur 15 hari setelah fertilisasi.

Pencegahan hama dan penyakit menggunakan insektisida Curacron 500 EC 2 cc liter $^{-1}$ air, dan Dithane M-45 2 gram liter ${ }^{-1}$ air. Petrogenol digunakan untuk melindungi buah dari lalat buah. Insektisida dan Fungisida diberikan seminggu setelah pindah tanam, dan diberikan dengan interval dua minggu sekali.

Panen dilakukan dengan kriteria panen antara lain timbulnya jala yang sudah jelas di kulit buah, dan jala berubah warna dari hijau menjadi kuning. Peubah yang diamati adalah : panjang daun (cm), Lebar daun $(\mathrm{cm})$, Diameter batang $(\mathrm{cm})$, Umur berbunga (hari), Lingkar buah $(\mathrm{cm})$, Berat buah $(\mathrm{kg})$, Tebal daging buah $(\mathrm{cm})$, dan kadar Gula (\%).

perlakuan yang diberikan dapat dilihat pada Tabel 1. Pada Tabel 2. Ditampilkan hasil pengamatan terhadap pertumbuhan generatif tanaman melon. 
Tabel 1. Rekap Rata-Rata Pertumbuhan Vegetatif Tanaman Melon

\begin{tabular}{|c|c|c|c|}
\hline Perlakuan & $\begin{array}{c}\text { Panjang Daun } \\
(\mathrm{Cm})\end{array}$ & $\begin{array}{c}\text { Lebar Daun } \\
(\mathrm{Cm})\end{array}$ & $\begin{array}{c}\text { Diameter Batang } \\
(\mathrm{Cm})\end{array}$ \\
\hline Tanpa BGG & 17,58 a & $19,28 \quad \mathrm{a}$ & $0,60 \mathrm{a}$ \\
\hline Pupuk BGG $1 \mathrm{ml} \mathrm{liter}^{-1}$ air & $21,26 \mathrm{~b}$ & 22,33 & $0,86 \mathrm{~b}$ \\
\hline Pupuk BGG $2 \mathrm{ml} \mathrm{liter}^{-1}$ air & $23,63 \mathrm{c}$ & 25,26 & $1,04 \mathrm{c}$ \\
\hline Pupuk BGG $3 \mathrm{ml} \mathrm{liter}^{-1}$ air & $27,66 \mathrm{~d}$ & 29,31 & $1,35 \mathrm{e}$ \\
\hline Pupuk BGG $4 \mathrm{ml}$ liter $^{-1}$ air & $25,00 \mathrm{c}$ & 27,00 & $1,09 \mathrm{~d}$ \\
\hline
\end{tabular}

Angka-angka yang diikuti oleh huruf kecil yang sama berbeda tidak nyata menurut DMRT p0.05

Tabel 2. Rekap Rata-Rata Pertumbuhan Generatif Tanaman Melon

\begin{tabular}{|c|c|c|c|c|c|c|c|}
\hline Perlakuan & $\begin{array}{r}\mathrm{U} \\
\text { berl } \\
(1\end{array}$ & $\begin{array}{l}\text { ur } \\
\text { nga } \\
\text { ri) }\end{array}$ & $\begin{array}{c}\text { Lingkar } \\
\text { buah } \\
(\mathrm{Cm})\end{array}$ & $\begin{array}{l}\text { Berat buah } \\
\quad(\mathrm{g})\end{array}$ & $\begin{array}{r}\text { Tebal c } \\
\text { buc } \\
(\mathrm{Cr} \\
\end{array}$ & ging & $\begin{array}{c}\text { Kadar Gula } \\
(\%)\end{array}$ \\
\hline Tanpa BGG & 19,25 & $\mathrm{e}$ & 34,19 a & $0,60 \mathrm{a}$ & 2,63 & $\mathrm{a}$ & 6,50 \\
\hline Pupuk BGG $1 \mathrm{ml} \mathrm{liter}^{-1}$ air & 17,00 & $\mathrm{~d}$ & $41,50 \mathrm{~b}$ & $0,86 \mathrm{~b}$ & 3,58 & $\mathrm{~b}$ & $8,75 \quad b$ \\
\hline Pupuk BGG $2 \mathrm{ml} \mathrm{liter}^{-1}$ air & 15,25 & $\mathrm{c}$ & $43,19 \mathrm{c}$ & $1,04 \mathrm{c}$ & 3,91 & $\mathrm{c}$ & $10,25 \mathrm{c}$ \\
\hline Pupuk BGG $3 \mathrm{ml} \mathrm{liter}^{-1}$ air & 12,25 & $\mathrm{a}$ & $46,19 \mathrm{~d}$ & $1,35 \mathrm{e}$ & 4,41 & $\mathrm{e}$ & $12,25 \mathrm{~d}$ \\
\hline Pupuk BGG $4 \mathrm{ml}$ liter $^{-1}$ air & 13,50 & $\mathrm{~b}$ & $45,58 \mathrm{~d}$ & $1,09 \mathrm{~d}$ & 4,16 & $\mathrm{~d}$ & $10,63 \mathrm{c}$ \\
\hline
\end{tabular}

Angka-angka yang diikuti oleh huruf kecil yang sama berbeda tidak nyata menurut DMRT p0.05

\section{Pembahasan}

Pertumbuhan vegetatif tanaman melon tanpa BGG dan yang diberi BGG berbeda nyata untuk seluruh parameter pertumbuhan vegetatif, dimana tanpa BGG pertumbuhan tanaman melon menjadi lebih rendah. Kondisi ini disebabkan karena tanaman hanya mendapatkan asupan hara dari pupuk organic dan pupuk NPK yang diberikan setengah dosis anjuran. Diduga pupuk NPK yang diberikan tidak dapat memenuhi kebutuhan unsur hara yang dibutuhkan tanaman melon. Fenomena ini sama dengan hasil penelitian yang dilakukan Surtinah (2017 b), dimana tanaman jagung manis yang tidak diberi Bio Ekstrim pertumbuhannya menjadi lebih rendah dibandingkan dengan yang diberi pupuk Bio ekstrim, dimana Bio ekstrim juga mengandung unsur hara makro dan mikro yang dibutuhkan oleh tanaman jagung manis.

Perlakuan BGG yang terbaik adalah $3 \mathrm{ml}$ liter $^{-1}$ air untuk seluruh parameter pengamatan. Kondisi ini merupakan kondisi terbaik dari pertumbuhan tanaman melon akibat pemberian BGG. Diduga konsentrasi 3 ml liter ${ }^{-1}$ air sudah dapat memenuhi kebutuhan yang diinginkan oleh tanaman untuk menstimulir pertumbuhan dan perkembangan organ-organ vegetatif tanaman. Pertumbuhan dan perkembangan organ vegetatif tanaman akan berdampak positif bagi produksi tanaman tersebut. Kecukupan unsur hara yang dibutuhkan akan memberikan produksi terbaik bagi tanaman yang dibudidayakan (Surtinah, 2007).

Pada konsentrasi yang tepat mikroorganisme yang terdapat di dalam BGG akan menjalankan perannya tanpa ada kompetisi diantara mikroorganisme tersebut. Actinomycetes, Azotobacter sp, Azospirillium sp, Rhizobium sp, Psedomonas, Lactobacillus sp, Bacilus sp, Cytophaga sp, Streptomycetes sp, Saccharomyces, Selulotik, BPF, Mycoriza, Tricoderma. Azotobacter sp dan Azospirillum sp akan menjalankan peranannya secara maksimal, terutama dlam proses penambatan Nitrogen yang akan digunakan tanaman setelah dirombak menjadi asam amino dan protein. Protein berperan dalam membentuk protoplasma yang peranannya sebagai wadah metabolisme dan akan menstimulir proses 
pembelahan sel dan pemanjangan sel (Pujisiswanto, dan Pangaribuan, 2008).

Mikoriza yang terkandung di dalam BGG akan menjadi jembatan dalam mendapatkan air pada lokasi yang jauh dari zona perakaran tanaman, dan mikoriza ini menjadi penghalang biologis terhadap infeksi pathogen akar, keberadaan mikoriza akan meningkatkan auksin yang berperan sebagai hormone pertumbuhan, mikoriza juga akan membuat tanaman lebih tahan terhadap kondisi kekeringan dibandingkan dengan tanpa adanya mikoriza di zona perakaran (Sembiring, dkk., 2013).

Kresnatita, Koesrihati, dan Santoso (2012) melaporkan bahwa keberadaan Nitrogen dapat meningkatkan laju fotosintesis yang pada gilirannya akan meningkatkan jumlah asimilat yang dihasilkan oleh tanaman. Unsur P dan $\mathrm{K}$ yang terkandung dalam BGG berperan dalam menstimulir pertumbuhan akar, mempercepat tanaman memasuki masa senil, dan tahan terhadap penyakit. Sedangkan unsur $\mathrm{K}$ peranannya dalam membentuk protein dan karbohidrat, memperkuat tumbuh tanaman sehingga gugur daun dapat dihindari, menstimulir bukaan stomata (Surtinah, 2012).

Zat pengatur tumbuh yang ada di dalam BGG seperti auksin membantu prose terbentuknya akar menjadi lebih baik, pembungaan, dan pembuahan. Sitokinin akan membantu metabolism pada tanaman terutama pada proses pembelahan sel. Giberelin menstimulir pembelahan dan pemanjangan sel (Surtinah, 2017 b).

Umur berbunga tanaman melon lebih cepat dibandingkan dengan deskripsi

\section{KESIMPULAN}

Perlakuan BGG yang terbaik adalah $3 \mathrm{ml}$ liter $^{-1}$ air, yang memberikan pertumbuhan varietas Sakata Glamour, yaitu 15-17 hari. Fenomena ini diduga disebabkan $P$ tersedia bagi tanaman akibat dari kinerja mikroorganisme pelarut posfat dapat menyediakan $\mathrm{P}$ dalam jumlah yang cukup (Surtinah, 2008).

Kadar gula yang tinggi pada penelitian ini diduga disebabkan karena terjadi peningkatan serapan $\mathrm{K}, \mathrm{Mg}$, dan $\mathrm{Mn}$, karena unsur ini berperan dalam meningkatkan peranan enzim amylase, sehingga pembentukan gula juga akan meningkat (Surtinah, 2012).

Pada konsentrasi BGG yang lebih tinggi terjadi penurunan pertumbuhan dan produksi, hal ini diduga karena kepekatan di lingkungan luar tanaman menjadi lebih tinggi sehingga cairan yang kepekatannya lebih tinggi tidak dapat masuk ke dalam jaringan tanaman (Surtinah, 2007). Tingginya konsentrasi dapat juga menyebabkan terjadinya kompetisi diantara mikroorganisme yang ada pada BGG dalam memperebutkan bahan makanan dan energy, sehingga mikroba tersebut akan kekurang asupan makanan yang dibutuhkan yang menyebabkan kierjanya menjadi rendah (Simanungkalit, Didi, Rasti, Diah, dan Wiwik, 2006).

Produksi terbaik diperoleh dengan pemberian BGG $3 \mathrm{ml} \mathrm{liter}^{-1}$ air. Hal ini ada hubungannyadengan pertumbuhan yang baik pada konsentrasi yang sama. Akibatnya hasil asimilasi yang diperoleh akan diakumulasikan ke bagian buah sebagai hasil produksi dari melon (Surtinah, 2008). Surtinah (2016) melaporkan jumlah daun dan panjang daun berhubungan erat dalam proses pembentukan kadar gula biji jagung manis.

dan produksi melon yang paling bagus dibandingkan dengan perlakuan lainnya. 


\section{UCAPAN TERIMA KASIH}

Terimakasih kepada seluruh staf, dosen, dan mahasiswa yang berperan dalam menyelesaikan penelitian ini.

\section{DAFTAR PUSTAKA}

Anianty A, 2008. Uji Efektivitas Pupuk Organik (BIO-ORGANIK FERTILIZER) dalam Mensubtitusi Kebutuhan Pupuk pada Tanaman Caisin (Brassica chinensis). Institut Pertanian Bogor.

Anonim, 2014. Aplikasi Bioto Grow Gold. Jakarta

Kresnatita, S., Koesriharti, K., \& Santoso, M. (2012). Pengaruh rabuk organik terhadap pertumbuhan dan hasil tanaman jagung manis. The Indonesian Green Technology Journal, 1(3), 8-17.

Panupesi, H. (2013). KEMAMPUAN MENINGKATKAN HASIL TANAMAN MELON (Cucumis melo, L) DENGAN PEMUPUKAN POSFOR DAN KONSENTRASI GANDASIL B PADA TANAH GAMBUT PEDALAMAN. Agrienvi, 7(1), 916.

Perimantoro, H., 2002. Memupuk Tanaman Sayur. Penebar Swadaya. Jakarta

Pujisiswanto, H., \& Pangaribuan, D. (2008). Pengaruh dosis kompos pupuk kandang sapi terhadap pertumbuhan dan produksi buah tomat. In Prosiding Seminar Nasional Sains dan TeknologiII (pp. 17-18).

Sembiring, Y. R. V., Nugroho, P. A., \& Istianto, I. (2013). KAJIAN
Terimakasih untuk Tim Editor JIP yang memberikan kesempatan untuk menerbitkn artikel ini.

\section{PENGGUNAAN \\ MIKROORGANISME TANAH UNTUK MENINGKATKAN EFISIENSI PEMUPUKAN PADA TANAMAN KARET. Warta Perkaretan, 32(1), 7-15.}

Simanungkalit,R., Didi., Rasti., Diah., Wiwik., 2006. Pupuk Organik dan Pupuk Hayati Organik Fertilizer dan Biofertilizer, Balai Besar Penelitian dan Pengembangan Sumberdaya Lahan Pertanian, Jawa Barat

Sudjianto, U., \& Krestiani, V. (2009). Studi pemulsaan dan dosis NPK pada hasil buah melon (Cucumis melo L). Sains dan Teknologi, 2(1).

SURTINAH, S. (2007). MENGUJI 5 MACAM PUPUK DAUN DENGAN MENGUKUR KADAR GULA TOTAL BIJI JAGUNG MANIS (Zea mays saccharata). Jurnal Ilmiah Pertanian, 3(2), 1-6.

SURTINAH, S. (2008). W AKTU PANEN YANG TEPAT MENENTUKAN KANDUNGAN GULA BIJI JAGUNG MANIS (Zea mays saccharata). Jurnal Ilmiah Pertanian, 4(2), 1-7.

Surtinah, S. (2012). KORELASI ANTARA WAKTU PANEN DAN KADAR GULA BIJI JAGUNG MANIS (Zea mays 
saccharata Sturt). Jurnal Ilmiah Pertanian, 9(1), 1-5.

Surtinah, S. (2017 a). Evaluasi Deskriptif Umur Panen Melon (Cucumis melo, L) Di Pekanbaru. Jurnal Ilmiah Pertanian, 14(1), 65-71.

Surtinah, S. (2017 b). POTENSI HASIL JAGUNG MANIS (Zea mays saccharata, Sturt) DENGAN PEMBERIAN PAKET TEKNOLOGI PUPUK DAN ZAT PENGATUR TUMBUH. Jurnal BiBieT, 2(1), 37-44.

Surtinah, S. $(2017$ c). Pertumbuhan Vegetatif dan Kadar Gula Biji Jagung Manis (Zea mays saccharata, Sturt) di Pekanbaru. Jurnal Ilmiah Pertanian, 13(2).
Surtinah, S., Nurwati, N. (2018). Selecting the Right Varieties in Riau Main Island: Sweet Corn Context. In IOP Conference Series: Earth and Environmental Science (Vol. 156, No. 1, p. 012062). IOP Publishing.

Susi, N., Surtinah, S., \& Rizal, M. (2018). Penguiian Kandungan Unsur Hara Pupuk Organik Cair (POC) Limbah Kulit Nenas. Jurnal Ilmiah Pertanian, 14(2). 